\title{
Interaction between vitamin A supplementation and chronic malnutrition on child development
}

\author{
Interação entre suplementação de vitamina A e desnutrição crônica \\ no desenvolvimento infantil
}

Luciano Lima Correia (http://orcid.org/0000-0001-8948-8660) ${ }^{1}$

Hermano Alexandre Lima Rocha (https://orcid.org/0000-0001-9096-0969) ${ }^{1}$

Jocileide Sales Campos (http://orcid.org/0000-0002-1582-4091) ${ }^{2}$

Anamaria Cavalcante e Silva (http://orcid.org/0000-0003-3483-2211) ${ }^{2}$

Dirlene Mafalda Ildefonso da Silveira (http://orcid.org/0000-0001-5641-3689) ${ }^{2}$

Márcia Maria Tavares Machado (http://orcid.org/0000-0002-0149-5792) ${ }^{1}$

Alvaro Jorge Madeiro Leite (http://orcid.org/0000-0002-8691-5986) ${ }^{1}$

Antonio José Ledo Alves da Cunha (https://orcid.org/0000-0003-3592-1849) ${ }^{3}$

\footnotetext{
${ }^{1}$ Departamento de Saúde Comunitária, Faculdade

de Medicina, Universidade Federal do Ceará. R. Prof. Costa Mendes $1608 / 5^{\circ}$, Rodolfo Teófilo. 60430140 Fortaleza CE Brasil. correialuciano@

hotmail.com

${ }^{2}$ Centro Universitário

Unichristus. Fortaleza CE

Brasil.

${ }^{3}$ Departamento de Pediatria, Faculdade de Medicina, Universidade Federal do Rio de Janeiro. Rio de Janeiro RJ Brasil.
}

\begin{abstract}
200 million pre-school age children are not developing properly. Delays in child development are associated with multiple factors. This study aims to analyze if vitamin A supplementation is associated with improved development and how this effect could be mediated by nutritional status. Population-based study surveyed a representative sample of 8000 households, 1232 children 0-35 months, in the state of Ceará, Brazil. The variables analysed included child developmental status, nutritional determinants and confounding factors. The main effects and interactions were evaluated using Cox regressive models. Vitamin A supplementation showed protective effect to delay in cognitive and motor development modified by interaction with nutritional status. While well-nourished supplemented children presented a $67 \%$ lower risk of cognitive delay (adjusted PRR $=0.33$ [0.21-0.53]), stunted children had no benefit from supplementation (adjusted PRR $=0.97[0.39-2.40])$. Vitamin A supplementation has a protective effect on child development, but not in stunted children. This suggests that supplementation is effective in promoting child development, especially if associated to a joint effort to improve the nutritional status of children, given the importance of this mediator.

Key words Vitamin A, Malnutrition, Child development, Nutrition policy
\end{abstract}

Resumo Duzentos milhões de crianças em idade pré-escolar não estão se desenvolvendo adequadamente. Os atrasos no desenvolvimento estão associados a múltiplos fatores. Este estudo pretende analisar se a suplementação de vitamina A está associada a melhor desenvolvimento e a forma como esse efeito pode ser mediado pelo estado nutricional. Estudo de base populacional com amostra de 8.000 famílias, 1.232 crianças 0-35 meses, no estado do Ceará, Brasil. As variáveis analisadas incluíram desenvolvimento, determinantes nutricionais e fatores de confusão. Os efeitos e as interações foram avaliados utilizando modelos regressivos de Cox. A suplementação de vitamina A foi protetora para atraso no desenvolvimento cognitivo e motor modificado pela interação com o estado nutricional. Crianças suplementadas bem nutridas apresentaram um risco 67\% menor de atraso cognitivo (PRR ajustado $=033\left[\begin{array}{ll}0 & 21-0\end{array}\right.$ 53]), já as crianças desnutridas não se beneficiaram (PRR ajustado = 097 [0 39-2 40]). A suplementação tem um efeito protetor sobre o desenvolvimento, mas não em crianças desnutridas. Isso sugere que a suplementação é eficaz na promoção do desenvolvimento, especialmente se associada a um esforço para melhorar o estado nutricional infantil, dada a importância desse mediador.

Palavras-chave Vitamina A, Desnutrição, Desenvolvimento infantil, Politica de nutrição 


\section{Introduction}

It is estimated that, worldwide, over 200 million pre-school age children are not developing properly ${ }^{1}$. Although there are few population estimates of child developmental delay, it is believed that the vast majority of cases occur in developing countries ${ }^{2,3}$. In low- and middle-income countries $36.8 \%$ of children aged from 3 to 4 years performed poorly in development tests ${ }^{4}$.

Children who do not reach their full development do not achieve adequate learning, behavior, and mental and physical wellbeing; display poorer performance at school; and earn lower wages as adults. This perpetuates a cycle of poverty and continuously impaired human development ${ }^{5,6}$.

Delays in child development are associated with nutritional, socioeconomic and family environment related factors, such as maternal depression $^{7}$, maternal work ${ }^{8}$, exposure to violence, and others ${ }^{1}$. Of the recognized contributing factors, child undernutrition and micronutrient deficiency ${ }^{9}$ are often cited as the most important, and the specific deleterious effect of malnutrition on child development has broad scientific confirmation $^{10-13}$. The effect of micro-nutrients, such as folic acid, iron, iodine, and vitamin A have been investigated in several studies ${ }^{14}$, with clear relationships directly observed for iron ${ }^{15}$ and iodine deficiency ${ }^{16}$.

Regarding vitamin A, few studies so far have yielded conclusive results. Supplementation at birth has tended to show a small positive effect on child development at three years of $\mathrm{age}^{17}$; however this effect was not statistically significant, and when vitamin A was administered to very low birth weight babies, no effect was observed $^{18}$. In animal models, it was found that the use of megadoses of vitamin A can lead to brain damage $^{19,20}$, injury to motor functions ${ }^{21}$, and modulation of immunity ${ }^{22}$ (effects associated with increased oxidative stress $\left.{ }^{19-21,23,24}\right)$. In other studies, vitamin A supplementation has reduced morbidity and mortality in populations with a high prevalence of malnutrition ${ }^{22,25}$.

Therefore, this study aims first, to analyze if vitamin A megadose supplementation is associated with improved child development, and second, to consider how this possible effect could be mediated by nutritional factors at a population level in the impoverished Ceará, in the northeastern region of Brazil. Ceará hosts the world's largest population living under semi-arid climatic conditions.

\section{Methods}

\section{Study type and population}

This population-based cross-sectional study surveyed a representative sample of households in the state of Ceará, Northeast Brazil, collecting socioeconomic, health, and nutritional data on families, women at reproductive age, and preschool aged children aged 0-35 months, in 2007.

\section{Study site}

Ceará is one of the poorest states in Brazil, with its whole $145000 \mathrm{~km} 2$ territory situated within the vast semi-arid northeastern region of Brazil, and a population of 8.5 million. The main industries are commerce and tourism in the capital, Fortaleza ( $2 \cdot 3$ million inhabitants) and subsistence agriculture in the countryside, an area with recurrent periods of drought.

\section{Study sample}

We used cluster sampling with stratification between the capital Fortaleza and the rural municipalities. The sample size was calculated as 8000 households (after multiplication by a correction factor equal to two, covering the design effect of cluster sampling, plus a $10 \%$ increase to compensate for losses). These households were estimated to comprise about 35000 people, with 11000 women aged 1249 years, and 1500 children under 3 years old. To ensure accurate representation of the study population, we selected municipalities and households randomly, following a process of multistage sampling. In each rural municipality ten geographical areas were randomly selected, allowing representation of even the most remote areas. More details about the sampling methodology can be found elsewhere ${ }^{26}$.

\section{Study variables}

The variables analysed included child developmental status (the study's focus), potential nutritional determinants, and confounding factors. The main variables of interest are described below:

Child development: To detect suspected cases of cognitive and motor development delay in children, we used a simplified scale for developmental surveillance of children 0 to 3 years of age. This scale was developed by the Brazilian Ministry of Health for use by primary care health pro- 
fessionals as a screening instrument ${ }^{27}$. Children were evaluated as either achieving or not achieving selected cognitive and motor milestones by certain ages (Table 1). The upper limit of each age group evaluated was determined by the presence of just a residual number of children who had not yet reached the milestone (cases above 3 standard deviations of the mean in a distribution curve). Using this method, we found prevalence rates similar to expected in the literature ${ }^{4}$.

Vitamin A supplementation: Information on vitamin A supplementation was provided by the mother, with a recall period of 12 months prior to the interview. The child was considered to be supplemented with vitamin A if he/she received at least one dose of 100000 units during the period. In Brazil, children from 0 to 5 years receive vitamin A supplementation annually, both during vaccination campaigns and as a part of routine primary care services.

Nutritional Status: To assess children's nutritional status, three anthropometric indicators were used: weight-for-age (W/A), height-for-age (H/A) and weight-for-height $(\mathrm{W} / \mathrm{H})$. These were compared with the standards of the US National Center for Health Statistics, according to WHO recommendations. Deficits found were classified as follows: undernutrition, W/A $<-2$ Standard Deviation (SD); stunting, $\mathrm{H} / \mathrm{A}<-2 \mathrm{SD}$; and wasting, $\mathrm{W} / \mathrm{H}<-2 \mathrm{SD}$.

Food insecurity: This outcome was measured from the question that assessed food availability in the family, both in quantitative and qualitative terms.

Table 1. Parameters of child development (CD) and age groups evaluated.

\begin{tabular}{|c|c|c|c|}
\hline $\begin{array}{c}\text { CD } \\
\text { Components }\end{array}$ & $\begin{array}{c}\text { CD } \\
\text { Milestones }\end{array}$ & $\begin{array}{l}\text { Expected age } \\
\text { group for } \\
\text { reaching the } \\
\text { milestone }\end{array}$ & $\begin{array}{c}\text { Age group } \\
\text { considered } \\
\text { as delayed }\end{array}$ \\
\hline \multirow[t]{2}{*}{ Cognitive } & $\begin{array}{l}\text { Speak at } \\
\text { least } 3 \\
\text { words }^{1}\end{array}$ & $\begin{array}{l}15 \text { to } 18 \\
\text { months }\end{array}$ & $\begin{array}{l}18 \text { to } 24 \\
\text { months }\end{array}$ \\
\hline & $\begin{array}{l}\text { Speak a } \\
\text { simple } \\
\text { sentence }^{2}\end{array}$ & $\begin{array}{l}24 \text { to } 30 \\
\text { months }\end{array}$ & $\begin{array}{l}28 \text { to } 35 \\
\text { months }\end{array}$ \\
\hline \multirow[t]{2}{*}{ Motor } & $\begin{array}{l}\text { Stand up } \\
\text { without } \\
\text { support }\end{array}$ & $\begin{array}{l}9 \text { to } 12 \\
\text { months }\end{array}$ & $\begin{array}{l}12 \text { to } 17 \\
\text { months }\end{array}$ \\
\hline & $\begin{array}{l}\text { Walk } \\
\text { without } \\
\text { support }\end{array}$ & $\begin{array}{l}12 \text { the } 18 \\
\text { months }\end{array}$ & $\begin{array}{l}18 \text { to } 23 \\
\text { months }\end{array}$ \\
\hline
\end{tabular}

${ }^{1}$ Excluding names of family members and pets; ${ }^{2}$ Combining at least two words in a phrase indicating action.
Birth weight: Information was obtained from the child's health chart, and, when this was unavailable, from the mothers.

Breastfeeding: This was recorded as a binary variable, differentiating between children who were breastfed for any length of time and children who never received breast milk.

Child weighing: Whether there was any record of the child's weight plotted on a growth chart in the previous 3 months.

The variables considered as potential confounding factors were: child age and sex, family characteristics (including per capita monthly income, urban or rural home location, participation in cash transfer programs, level of schooling of the head of the family, and whether the father was living at home), availability of tap water and toilet facilities at home, and maternal features (level of education and nutritional status).

\section{Data collection}

Information was collected from September 2007 to February 2008 using three questionnaires on households, mothers, and children, administered by 25 interviewers/evaluators with graduate level qualifications. The child development assessment was conducted by the evaluators, who were properly trained in the application of the simplified child development scale, as developed by the Ministry of Health. Weight of mothers and their children were measured using portable electronic scales, Tanita ${ }^{\circledR}$ type, with a capacity of $150 \mathrm{~kg}$ and $0 \cdot 1 \mathrm{~kg}$ calibration. Height was measured with a portable scale with a range of $30-110 \mathrm{~cm}$, with a precision of $1 \mathrm{~mm}$. Children < 24 months were measured horizontally and those 24-35 months in a standing position.

\section{Data processing and analysis}

Data were entered twice using EpiInfo 2000 (WHO/CDC), and analysed using Statistical Package for the Social Sciences 17·0 (Chicago, IL, USA), with the Anthro program (Centers for Disease Control and Prevention, Atlanta, GA, USA) used to analyse the anthropometric data.

Analysis included three main steps:

1: Describe and identify the main nutritional effects on child development. The initial analysis involved tabulating the frequency distributions of all selected variables. The prevalence rate ratio (PRR) was estimated, equivalent to the ratio of cumulative incidence in cohort studies. To analyse the impact of nutritional status on cognitive and 
motor development of children, models were constructed using Cox Hazard Regression with punctual time and robust variance in single and multiple approaches. Assuming a constant period of risk, the Cox model can be adapted to estimate PR in cross-sectional studies, and in these studies this measure seems to produce better estimates of risk than the Odds Ratio ${ }^{28}$.

2: Identify possible interactions between nutritional effects, regardless of significant association. To test possible interactions between the factors, tests of maximum likelihood ratios by stratified analysis were first used. To access the interaction between the multiplicative main effect and other determinants, multiple Cox regression models were constructed with factorial analysis, in which the tested determinant, the main effect, and the multiplicative interaction term were present. We have presented data only on significant interactions $(\mathrm{p}<0 \cdot 10)$.

3: Subgroup analysis for interacting factors. When effect modification was identified we performed analyses of subgroups according to the variable modifier. The variables with $\mathrm{p}<0.10$ in the simple analysis models were evaluated as potential confounders via hierarchised multivariate stratified analysis, and also with Cox regression. The association of independent variables was expressed as a prevalence rate with $95 \%$ confidence intervals.

\section{Ethical}

All surveys were approved by the ethics committee of the institutions involved, the Brazilian Ministry of Health, the Ceará State Secretariat of Health and the Federal University of Ceará. All participants signed an informed consent form before entering the study.

\section{Results}

In 7890 households surveyed, a total of 1232 children in the age range 0-35 months were found. Of these children, $446(36 \cdot 2 \%)$ in the 18-35-month age group had their cognitive development evaluated. We found that $104(22 \cdot 2 \%)$ of them were suspected of a delay in the ability to speak (because they still could not speak three words, or could not articulate a simple sentence). Regarding motor development, 294 children (23.9\%) aged 12 to 23 months were evaluated, with 46 (15.6\%) presenting suspected motor delay (they were not able to stand up or could not walk a few steps without support). As a whole, $6 \cdot 8 \%$ of children presented both forms of delay, $23.4 \%$ one form or the other, and $69.7 \%$ presented no delay.

Table 2 shows the adjusted effects of selected nutritional factors on child development. Supplementation with vitamin A showed a strong protective effect: it was inversely associated with the three forms of delay studied. Children supplemented showed 53\% lower probability of cognitive delay $(\mathrm{p}<0.001), 48 \%$ lower probability of motor delay $(\mathrm{p}=0.023)$ and $44 \%$ lower probability of combined cognitive-motor delay $(\mathrm{p}=0.002)$, compared with children not supplemented. Chronic malnutrition was strongly associated with motor development, as stunted children presented $2 \cdot 2$ times greater risk of delay ( $\mathrm{p}$ $=0.013$ ) in comparison with children who were not stunted. Regarding cognitive delay, chronic malnutrition showed significant association in the bivariate analysis, and but this significance was not maintained in the adjusted analysis ( $\mathrm{p}$ $=0.090)$. Breastfeeding was strongly associated with successful motor development: children who never received breast milk had a 2.9 times higher occurrence of delays in motor development compared with children who had been breastfed ( $\mathrm{p}<0 \cdot 001)$.

Food security, although significantly associated with cognitive delay in the bivariate analysis, did not remain significant in the adjusted analysis.

Other nutritional factors analysed (such as birth weight, growth monitoring and acute malnutrition) showed no association with cognitive or motor development, both in crude and adjusted analysis (Table 2).

Because of the magnitude and consistency of the association between vitamin A supplementation and reduced likelihood of delay in child development, the identification of possible effect modifiers of this association using regressive models with multiplicative interaction terms was performed. A strong statistically significant interaction between chronic malnutrition and vitamin A supplementation was found, yielding values of $\mathrm{p}<0.015$ for cognitive delay, $\mathrm{p}<0.020$ for motor delay, and $<\mathrm{p} 0 \cdot 017$ for cognitive-motor delay. Through analysis of the prevalence rate in each group of interaction possible using stratified analysis for cross-categories of these determinants, it was observed that the relationship between Vitamin A megadose supplementation and chronic malnutrition was antagonistic and determinant for all three forms of developmental delay (motor, cognitive, motor and cognitive), 


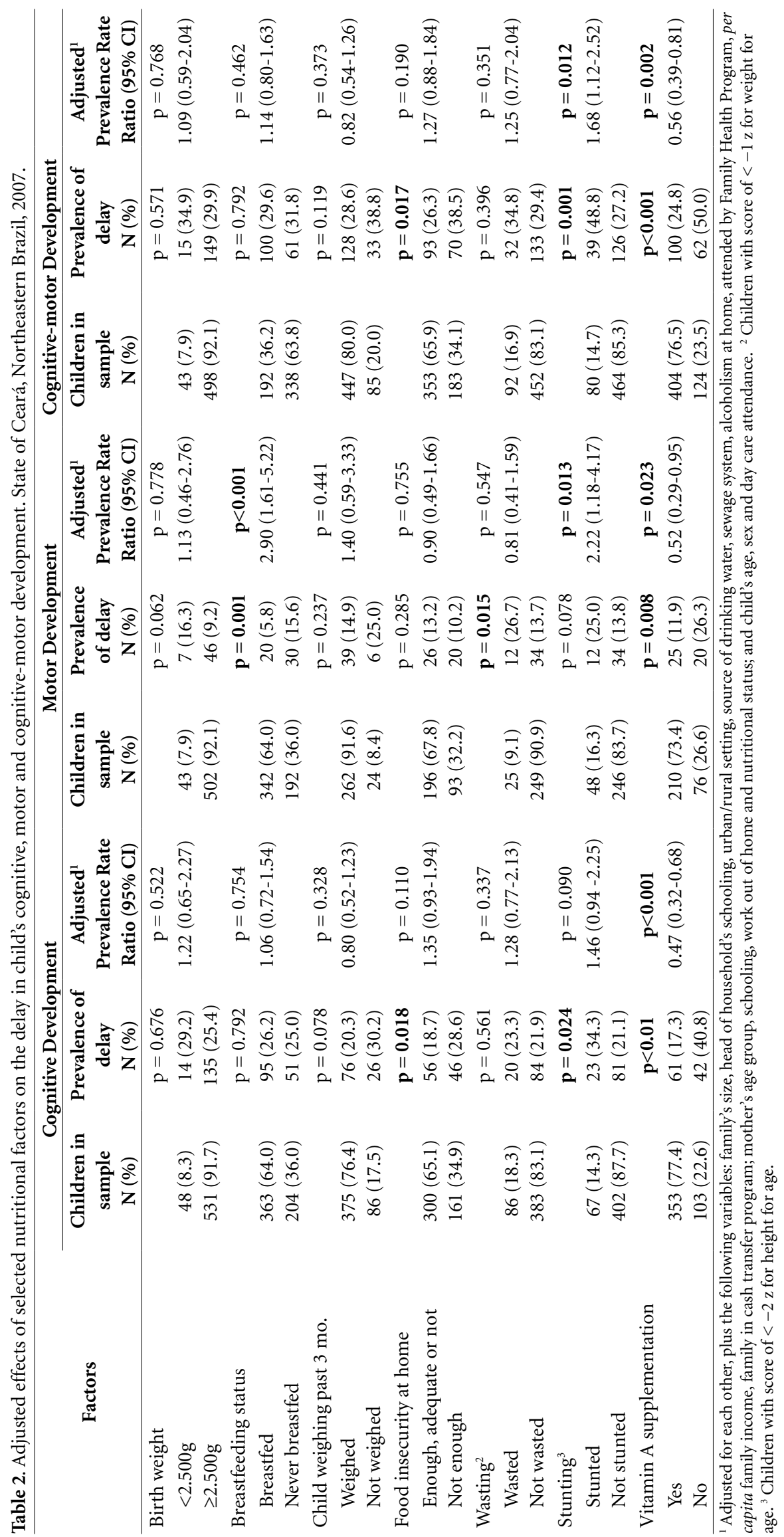


with the highest numerical relevance to cognitive delay. In this category, the difference between observed and expected prevalence rate was almost seven-fold. The expected prevalence rate for cognitive and motor delays were 6.7 and 1.6 times larger than those observed, respectively (Table 3 and Table 4).

It is apparent in Table 5 that non-stunted children benefited significantly from supplementation with vitamin $\mathrm{A}$, showing a reduction of $67 \%$ in the risk of cognitive delay (adjusted PRR $=0.33 ; 95 \%$ CI $0.21-0.53 ; \mathrm{p}<0.001)$. However, children who were chronically malnourished showed no significant benefit from supplementation with vitamin $\mathrm{A}$ (adjusted $\mathrm{PRR}=0.97$; 95\% CI 0.39-2.40; $\mathrm{p}=0.956$ ). A similar result was observed regarding motor development in non-stunted children, with supplementation of vitamin A reducing the risk of motor delay by $70 \%$ (adjusted PRR $=0 \cdot 30 ; 95 \%$ CI 0.15-0.62; p $=0.001)$. Vitamin A supplementation of stunted children was not associated with an increase nor decrease in the risk of motor delay (adjusted PRR $=1.64 ; 95 \%$ CI $0.35-7 \cdot 69 ; \mathrm{p}=0.525$ ).

The effects of interaction between chronic malnutrition and vitamin A supplementation have also been observed in relation to combined cognitive-motor development, with well-nourished children benefiting from protection, while chronically malnourished children showed no significant beneficial effect.

Finally, that the association between vitamin A supplementation and delay in child development remained highly statistically significant in the adjusted analysis, even after splitting of the database into 'malnourished' and 'not malnourished' children, with no confounding factors being identified.

\section{Discussion}

This study presents two main findings. First, suggests that supplementation with vitamin $\mathrm{A}$ has

Table 3. Stratified analysis of the interaction between chronic malnutrition and vitamin A supplementation and its effects on child cognitive, motor, and cognitive-motor development. State of Ceará, Northeastern Brazil, 2007.

\begin{tabular}{|c|c|c|c|c|c|c|c|}
\hline \multicolumn{8}{|c|}{ Delay in cognitive development: } \\
\hline Stunting & $\begin{array}{c}\text { Vitamin A } \\
\text { supplementation }\end{array}$ & $\begin{array}{l}\text { Number } \\
\text { of } \\
\text { children }\end{array}$ & $\begin{array}{l}\text { Number } \\
\text { of cases } \\
\text { of delay }\end{array}$ & $\begin{array}{l}\text { Prevalence } \\
\text { rate }\end{array}$ & $\begin{array}{c}\text { Crude } \\
\text { Prevalence Rate } \\
\text { Ratio } \\
(95 \% \mathrm{CI}) \\
\end{array}$ & $\begin{array}{l}\text { Attribu- } \\
\text { table } \\
\text { risk }\end{array}$ & $\begin{array}{c}\text { Adjusted } \\
\text { Prevalence Ratio } \\
(95 \% \mathrm{CI})^{\dagger}\end{array}$ \\
\hline Absent & Yes & 309 & 46 & 14.9 & 1 & 0 & 1 \\
\hline Absent & No & 83 & 35 & 42.2 & $2.83(1.3-4.1)$ & 27.3 & $4.91(1.4-17.8)$ \\
\hline Present & Yes & 44 & 15 & 34.1 & $2.29(1.3-4.1)$ & 19.2 & $3.29(1.2-9.0)$ \\
\hline Present & No & 20 & 7 & 35.0 & $2.35(1.1-5.2)$ & 20.1 & $2.39(0.95-6.0)$ \\
\hline \multicolumn{8}{|c|}{ Delay in motor development: } \\
\hline Stunting & $\begin{array}{c}\text { Vitamin A } \\
\text { supplementation }\end{array}$ & $\begin{array}{l}\text { Number } \\
\text { of } \\
\text { children }\end{array}$ & $\begin{array}{l}\text { Number } \\
\text { of cases } \\
\text { of delay }\end{array}$ & $\begin{array}{l}\text { Prevalence } \\
\text { rate }\end{array}$ & $\begin{array}{c}\text { Crude } \\
\text { Prevalence Rate } \\
\text { Ratio } \\
(95 \% \mathrm{CI}) \\
\end{array}$ & $\begin{array}{l}\text { Attribu- } \\
\text { table } \\
\text { risk }\end{array}$ & $\begin{array}{c}\text { Adjusted } \\
\text { Prevalence Ratio } \\
(95 \% \mathrm{CI})^{\dagger}\end{array}$ \\
\hline Absent & Yes & 174 & 15 & 8.6 & 1 & 0 & 1 \\
\hline Absent & No & 65 & 18 & 27.7 & $3.12(1.6-6.4)$ & 19.1 & $1.83(0.41-8.1)$ \\
\hline Present & Yes & 36 & 10 & 27.8 & $3.22(1.4-7.2)$ & 19.2 & $2.90(1.3-6.6)$ \\
\hline Present & No & 11 & 2 & 18.2 & $2.10(0.48-9.2)$ & 9.6 & $3.06(1.5-6.1)$ \\
\hline \multicolumn{8}{|c|}{ Delay in cognitive-motor development: } \\
\hline Stunting & $\begin{array}{c}\text { Vitamin A } \\
\text { supplementation }\end{array}$ & $\begin{array}{l}\text { Number } \\
\text { of } \\
\text { children }\end{array}$ & $\begin{array}{l}\text { Number } \\
\text { of cases } \\
\text { of delay }\end{array}$ & $\begin{array}{l}\text { Prevalence } \\
\text { rate }\end{array}$ & $\begin{array}{c}\text { Crude } \\
\text { Prevalence Rate } \\
\text { Ratio } \\
(95 \% \text { CI })\end{array}$ & $\begin{array}{l}\text { Attribu- } \\
\text { table } \\
\text { risk }\end{array}$ & $\begin{array}{c}\text { Adjusted } \\
\text { Prevalence Ratio } \\
(95 \% \mathrm{CI})^{\dagger}\end{array}$ \\
\hline Absent & Yes & 349 & 74 & 21.2 & 1 & 0 & 1 \\
\hline Absent & No & 101 & 50 & 49.5 & $2.33(1.6-3.3)$ & 28.3 & $2.42(1.1-4.5)$ \\
\hline Present & Yes & 54 & 26 & 48.1 & $2.27(1.5-3.6)$ & 26.9 & $2.07(1.3-3.5)$ \\
\hline Present & No & 23 & 12 & 52.2 & $2.46(1.3-4.5)$ & 31.0 & $2.17(1.5-3.1)$ \\
\hline
\end{tabular}

${ }^{\dagger}$ Adjusted for per capita monthly family income, child age and sex. 
Table 4. Interaction analysis between stunting and vitamin A supplementation for children's cognitive, motor, and cognitive-motor development delay, expressed in prevalence rate/ratio of adjusted prevalence ${ }^{\dagger}$.

\begin{tabular}{|c|c|c|}
\hline \multicolumn{3}{|c|}{ Cognitive development delay: } \\
\hline & Stunted & Not stunted \\
\hline Not supplemented & $35.0 / 2.39$ & $42.2 / 4.91$ \\
\hline Supplemented & $34.1 / 3.29$ & $14.9 / 1$ \\
\hline \multicolumn{3}{|c|}{$\begin{array}{l}\text { Contrast of multiplicative interaction: expected: } 16.15 \\
\text { Found } 2.39 \text { (causal antagonism) } \\
\text { Multiplicative interaction significance test: value of } \mathrm{p}< \\
0.015\end{array}$} \\
\hline \multicolumn{3}{|c|}{ Motor development delay: } \\
\hline & Stunted & Not stunted \\
\hline Not supplemented & $18.2 / 3.06$ & $27.7 / 1.83$ \\
\hline Supplemented & $27.8 / 2.90$ & $8.6 / 1$ \\
\hline \multicolumn{3}{|c|}{$\begin{array}{l}\text { Contrast of multiplicative interaction: expected: } 5.03 \\
\text { Found } 3.06 \text { (causal antagonism) } \\
\text { Multiplicative interaction significance test: }<\text { p value } \\
0.020\end{array}$} \\
\hline \multicolumn{3}{|c|}{ Cognitive-motor development delay: } \\
\hline & Stunted & Not stunted \\
\hline Not supplemented & $52.2 / 2.17$ & $49.5 / 2.42$ \\
\hline Supplemented & $48.1 / 2.07$ & $21.2 / 1$ \\
\hline \multicolumn{3}{|c|}{$\begin{array}{l}\text { Contrast of multiplicative interaction: expected: } 5 \cdot 00 \\
\text { Found } 2.17 \text { (causal antagonism) } \\
\text { Multiplicative interaction significance test (COX } \\
\text { regression): p-value }<0.017\end{array}$} \\
\hline
\end{tabular}

a protective effect against child developmental delay on a large scale. Second, suggest that this effect is selective, benefiting only those children who do not have chronic malnutrition. These findings are of great importance to public health. If confirmed, they may be formative in redirecting the strategy of nutritional programs worldwide, screening all children supplementation for malnutrition, for example ${ }^{25}$.

This is possibly the first study to suggest a positive association between vitamin A supplementation and child development at the population level, as a comprehensive search of available literature revealed only two studies that evaluated the effects of vitamin A on child development. The first study, a trial carried out in Indonesia, assessed the effect of vitamin A supplemented at birth on child development, and found a small beneficial effect at the age of 3 years $^{17}$. The second, conducted in the United States, studied the effects of neonatal vitamin A supplementation on very low birth weight babies, and found no positive effects ${ }^{29}$.

The positive effect of vitamin A supplementation found here proved to be of considerable benefit, but excluded a large group of very vulnerable children: the chronically malnourished. Supporting this result, laboratory studies in animal models have consistently shown that

Table 5. Adjusted prevalence rate ratio of cognitive and motor development delay in children supplemented and not supplemented with vitamin A, according to nutritional status ${ }^{\dagger}$. State of Ceará, 2007.

\begin{tabular}{|c|c|c|c|c|}
\hline Nutritional Status & $\begin{array}{c}\text { Supplementation with } \\
\text { vitamin A }\end{array}$ & $\begin{array}{l}\text { Crude Prevalence } \\
\text { Rate Ratio } \\
\text { (95\% confidence } \\
\text { interval) }\end{array}$ & $\begin{array}{c}\text { Adjusted Prevalence } \\
\text { Rate Ratio } \\
\text { (95\% confidence } \\
\text { interval) }\end{array}$ & Value of $p$ \\
\hline \multicolumn{5}{|c|}{ Cognitive development delay ${ }^{1}$ : } \\
\hline Without Stunting: & $\begin{array}{l}\text { Supplemented } \\
\text { Not supplemented }\end{array}$ & $\begin{array}{c}0.35(0.22-0.54) \\
1\end{array}$ & $\begin{array}{c}0.33(0.21-0.53) \\
1\end{array}$ & $<0.001$ \\
\hline With Stunting: & $\begin{array}{l}\text { Supplemented } \\
\text { Not supplemented }\end{array}$ & $\begin{array}{c}0.97(0.39-2.38) \\
1\end{array}$ & $\begin{array}{c}0.97(0.39-2.40) \\
1\end{array}$ & 0.956 \\
\hline \multicolumn{5}{|c|}{ Motor development delay ${ }^{2}$ : } \\
\hline Without Stunting: & $\begin{array}{l}\text { Supplemented } \\
\text { Not supplemented }\end{array}$ & $\begin{array}{c}0.31(0.15-0.61) \\
1\end{array}$ & $\begin{array}{c}0.30(0.15-0.62) \\
1\end{array}$ & 0.001 \\
\hline With Stunting: & $\begin{array}{l}\text { Supplemented } \\
\text { Not supplemented }\end{array}$ & $\begin{array}{c}1.52(0.33-6.97) \\
1\end{array}$ & $\begin{array}{c}1.64(0.35-7.69) \\
1\end{array}$ & 0.525 \\
\hline \multicolumn{5}{|c|}{ Cognitive-motor development delay ${ }^{3}$ : } \\
\hline Without Stunting: & $\begin{array}{l}\text { Supplemented } \\
\text { Not supplemented }\end{array}$ & $\begin{array}{c}0.42(0.29-0.61) \\
1\end{array}$ & $\begin{array}{c}0.43(0.30-0.63) \\
1\end{array}$ & $<0.001$ \\
\hline With Stunting: & $\begin{array}{l}\text { Supplemented } \\
\text { Not supplemented }\end{array}$ & $\begin{array}{c}0.92(0.46-1.82) \\
1\end{array}$ & $\begin{array}{c}0.87(0.43-1.74) \\
1\end{array}$ & 0.704 \\
\hline
\end{tabular}


supplementation with megadose supplements of vitamin A may cause brain, mitochondrial, pulmonary, and muscular damage, resulting in functional impairment. This effect is due to the increased oxidative stress that occurs because of reduction in the organic capacity for decreasing free radicals ${ }^{19-21,23,24}$. Chronic malnutrition (which involves repeated periods of insufficient calorific intake) also generates a state of oxidative stress, as has been demonstrated in laboratory animals ${ }^{30}$. In children, the effect of oxidative stress mediated by fasting is also seen as a factor contributing to developmental retardation ${ }^{10-13}$. This phenomenon is known as the nutritional stress hypothesis ${ }^{31}$. Vitamin A also has an important role in the modulation of immunity. Mice with vitamin A deficiency present defects in the activity of their immune cells, in addition to various effects on their immunoglobulins $s^{32}$. Also, stunted children have a higher risk of infections, that may also lead to developmental impairment ${ }^{33}$.

Vitamin A supplementation programs have been achieved on a global scale in the last 20 years, but instead of being a clearly defined beneficial intervention in health promotion, questions have been raised regarding the validity of the intervention. In 2013, the importance of vitamin A in reducing infant mortality was brought under additional scrutiny by the findings of the DEVTA study $^{34}$. Carried out in India, this was the largest cluster-randomized trial ever done regarding vitamin A supplementation programs. It found a non-significant mortality rate reduction of $4 \%$, (95\% CI $0 \cdot 89-1 \cdot 03, \mathrm{p}=0 \cdot 22)$, with no specific causes of mortality averted. Other evaluations of the effectiveness of supplementation have found contradictory results, depending largely on the presence of confounding conditions ${ }^{22,25}$. This can be attributed to the immunity modulator effect, or to subgroup effects of vitamin A (known as non-specific effects) $)^{35}$.

This study is one of the few initiatives to measure delay in child development as an epidemiological outcome. Although outcomes measured in the field are less accurate than outcomes measured in a clinical environment, this inaccuracy is offset with additional value in being comprehensive, as well as representative of real-world conditions.

The high prevalence $(30 \cdot 3 \%)$ of suspected cognitive-motor delay in children aged 12 to 35 months observed in this study are consistent with those found in a study in the wealthy southern region of Brazil, where $34 \%$ of children aged up to 12 months were suspected of developmental delay according to the Denver II screening test ${ }^{36}$.
Although overestimation is possible in our method to access development, this would suggest that the screening test used in this study is highly sensitive, and suitable for community screening of children with suspected delays (to be referred to higher level of care for diagnostic confirmation).

Chronic malnutrition presents serious repercussions for health and productivity 9 . In northeastern Brazil, chronic malnutrition is highly prevalent, affecting $12 \%$ of children under 3 years of age (a rate three times higher than is registered for acute malnutrition) ${ }^{37}$. A similar situation can be found in many other countries of the developing world, where rates of stunting range from 10 to $20 \%{ }^{1}$. Thus, considering the high prevalence of child chronic malnutrition, any indication that it is responsible for new deleterious effects to child health is of great concern.

\section{Limitations}

The fact that only about $30 \%$ of children have their cognitive and motor development evaluated reduced the statistical power of the sample and decreased the number of variables that could be included in the regression model. Cross-sectional studies do not allow to evaluate causality directly, and the factors found are only possible determinants. A simplification of the evaluation of the motor and cognitive development of children was necessary, but this is consistent with findings in other similar places.

\section{Conclusions}

Vitamin A supplementation undoubtedly has potential to benefit children's health. Nevertheless, the non-specific effects of supplementation (with different effects in subgroups as well as a possible effect of modulating the immune system though oxidative effects) must be considered. If the findings of this study are confirmed by longitudinal cohorts or community trials the suggested intervention would be to provide stunted children with more than vitamin A supplements, as this alone could present an increased risk to their development. The fact that stunting is an easily identified condition favours the implementation of interventions aimed at this group of children. In this study, we found a protective effect of vitamin A on child development, but only in well-nourished children. This suggests that supplementation is worthwhile and should be continued, in a joint effort to improve the nutritional status of children. 


\section{Key messages}

The vitamin A supplementation has an overall positive effect on child development.

The vitamin A supplementation has a non-specific effect on child development in stunted children.

The non-specific effects of supplementation with vitamin A should be considered.

\section{Collaborations}

LL Correia, HAL Rocha, AC Silva, JS Campos, DMI Silveira, MMT Machado, AJM Leite, AJLA Cunha have made substancial contributions to study conception and design and have made also substancial contributions to analysis and interpretation of data, as well as drafting the article and revising it critically for important intellectual content.

\section{References}

1. Walker SP, Wachs TD, Grantham-McGregor S, Black MM, Nelson CA, Huffman SL, Baker-Henningham H, Chang SM, Hamadani JD, Lozoff B, Gardner JM, Powell CA, Rahman A, Richter L. Inequality in early childhood: risk and protective factors for early child development. Lancet 2011; 378(9799):1325-1338.

2. Bornstein MH, Britto PR, Nonoyama Tarumi Y, Ota Y, Petrovic O, Putnick DL. Child development in developing countries: Introduction and methods. Child Dev 2012; 83(1):16-31.

3. Yousafzai AK, Rasheed MA, Rizvi A, Armstrong R, Bhutta ZA. Effect of integrated responsive stimulation and nutrition interventions in the Lady Health Worker programme in Pakistan on child development, growth, and health outcomes: a cluster-randomised factorial effectiveness trial. Lancet 2014; 384(9950):1282-1293.

4. McCoy DC, Peet ED, Ezzati M, Danaei G, Black MM Sudfeld CR, Fawzi W, Fink G. Early Childhood Developmental Status in Low- and Middle-Income Countries: National, Regional, and Global Prevalence Estimates Using Predictive Modeling. PLoS Med 2016; 13(6):e1002034.

5. Alderman $\mathrm{H}$. The economic cost of a poor start to life. J Dev Orig Health Dis 2010; 1(01):19-25.

6. Heckman JJ. Skill formation and the economics of investing in disadvantaged children. Science. 2006; 312(5782): 1900-1902.

7. Wachs TD, Black MM, Engle PL. Maternal depression: a global threat to children's health, development, and behavior and to human rights. Child Development Perspectives 2009; 3(1):51-59.

8. Moreira RS, Magalhaes LC, Dourado JS, Lemos SM, Alves CR. Factors influencing the motor development of prematurely born school-aged children in Brazil. Res Dev Disabil 2014; 35(9):1941-1951.
9. Walker SP, Wachs TD, Meeks Gardner J, Lozoff B, Wasserman GA, Pollitt E, Carter JA; International Child Development Steering Group. Child development: risk factors for adverse outcomes in developing countries. Lancet 2007; 369(9556):145-157.

10. Grantham-McGregor S, Cheung YB, Cueto S, Glewwe P, Richter L, Strupp B ; International Child Development Steering Group. Developmental potential in the first 5 years for children in developing countries. Lancet 2007; 369(9555):60-70.

11. Bateson P, Barker D, Clutton-Brock T, Deb D, D’udine B, Foley RA, Gluckman P, Godfrey K, Kirkwood T, Lahr MM, McNamara J, Metcalfe NB, Monaghan P, Spencer HG, Sultan SE. Developmental plasticity and human health. Nature 2004; 430(6998):419-421.

12. Levitsky DA, Strupp BJ. Malnutrition and the brain: changing concepts, changing concerns. J Nutr 1995; 125(8):2212S.

13. Pollitt E, Leibel RL, Greenfield D. Brief fasting, stress, and cognition in children. Am J Clin Nutr 1981; 34(8):1526-1533.

14. Lima AA, Anstead GM, Zhang Q, Figueiredo IL, Soares AM, Mota RM, Lima NL, Guerrant RL, Oriá RB. Effects of glutamine alone or in combination with zinc and vitamin $\mathrm{A}$ on growth, intestinal barrier function, stress and satiety-related hormones in Brazilian shantytown children. Clinics (Sao Paulo) 2014; 69(4):225-233.

15. Sachdev H, Gera T, Nestel P. Effect of iron supplementation on mental and motor development in children systematic review of randomised controlled trials Public Health Nutr 2005; 8(02):117-132.

16. Qian M, Wang D, Watkins WE, Gebski V, Yan YQ, Li $M$, Chen ZP. The effects of iodine on intelligence in children: a meta-analysis of studies conducted in China. Asia Pac J Clin Nutr 2005; 14(1):32-42. 
17. Humphrey JH, Agoestina T, Juliana A, Septiana S, Widjaja H, Cerreto MC, Wu LS, Ichord RN, Katz J, West Junior KP. Neonatal vitamin A supplementation: effect on development and growth at $3 \mathrm{y}$ of age. Am J Clin Nutr 1998; 68(1):109-117.

18. Christian P, Murray-Kolb LE, Khatry SK, Katz J, Schaefer BA, Cole PM, Leclerq SC, Tielsch JM. Prenatal micronutrient supplementation and intellectual and motor function in early school-aged children in Nepal. JAMA 2010; 304(24):2716-2723.

19. Oliveira MR, Moreira JCF. Acute and chronic vitamin A supplementation at therapeutic doses induces oxidative stress in submitochondrial particles isolated from cerebral cortex and cerebellum of adult rats. Toxicol Lett 2007; 173(3):145-150.

20. Oliveira MR, Silvestrin RB, Souza TM, Moreira JCF. Oxidative stress in the hippocampus, anxiety-like behavior and decreased locomotory and exploratory activity of adult rats: effects of sub acute vitamin A supplementation at therapeutic doses. Neurotoxicology 2007; 28(6):1191-1199.

21. Oliveira MR, Bittencourt Pasquali MA, Silvestrin RB, Souza TM, Moreira JCF. Vitamin A supplementation induces a prooxidative state in the striatum and impairs locomotory and exploratory activity of adult rats. Brain Res 2007; 1169:112-119.

22. Rocha H, Silva A, Correia L, Campos J, Machado M, Leite A, Cunha AJ. Effects of Vitamin A supplementation on child morbidity: A twenty-year time series analysis in the northeastern region of Brazil. Matern Child Health J 2015; 19(7):1652-1656.

23. Pasquali MA, Schnorr CE, Feistauer LBH, Gelain DP, Moreira JCF. Vitamin A supplementation to pregnant and breastfeeding female rats induces oxidative stress in the neonatal lung. Reprod Toxicol 2010; 30(3):452456.

24. Oliveira MR, Oliveira MWS, Behr GA, Moreira JCF. Vitamin A supplementation at clinical doses induces a dysfunction in the redox and bioenergetics states, but did change neither caspases activities nor TNF- $\alpha$ levels in the frontal cortex of adult Wistar rats. J Psychiatr Res 2009; 43(8):754-762.

25. Haider BA, Bhutta ZA. Neonatal vitamin A supplementation: time to move on. Lancet 2015; 385(9975):1268-1271.

26. Correia LL, Silva AC, Campos JS, Andrade FMO, Silveira DMI, Machado MMT, Rocha HAL, Cunha AJLA. Metodologia das Pesquisas Populacionais de Saúde Materno-Infantil: uma série transversal realizada no Estado do Ceará de 1987 a 2007. Revista Brasileira de Saúde Materno Infantil 2014; 14(4):353-362.

27. Melo Figueiras AC, Puccini RF, Silva EMK, Pedromônico MRM. Avaliação das práticas e conhecimentos de profissionais da atenção primária à saúde sobre vigilância do desenvolvimento infantil Evaluation of practices and knowledge among primary health care professionals in relation. Cad Saude Publica 2003; 19(6):1691-1699.
28. Barros AJ, Hirakata VN. Alternatives for logistic regression in cross-sectional studies: an empirical comparison of models that directly estimate the prevalence ratio. BMC medical research methodology 2003; 3:21.

29. Ambalavanan N, Tyson JE, Kennedy KA, Hansen NI, Vohr BR, Wright LL, Carlo WA; National Institute of Child Health and Human Development Neonatal Research Network. Vitamin A Supplementation for Extremely Low Birth Weight Infants: Outcome at 18 to 22 Months. Pediatrics 2005; 115(3):e249-e254.

30. Sodhi C, Rana S, Mehta S, Vaiphei K, Attri S, Thakur S, Mehta S. Study of oxidative stress in isoniazid-induced hepatic injury in young rats with and without protein-energy malnutrition. J Biochem Toxicol 1996; 11(3):139-146.

31. Nowicki S, Searcy W, Peters S. Brain development, song learning and mate choice in birds: a review and experimental test of the" nutritional stress hypothesis". J Comp Physiol A Neuroethol Sens Neural Behav Physiol 2002; 188(11-12):1003-1014.

32. Mora JR, Iwata M, von Andrian UH. Vitamin effects on the immune system: vitamins A and D take centre stage. Nat Rev Immunol 2008; 8(9):685-698.

33. Berkman DS, Lescano AG, Gilman RH, Lopez SL, Black MM. Effects of stunting, diarrhoeal disease, and parasitic infection during infancy on cognition in late childhood: a follow-up study. Lancet 2002; 359(9306):564-571.

34. Awasthi S, Peto R, Read S, Clark S, Pande V, Bundy D. Vitamin A supplementation every 6 months with retinol in 1 million pre-school children in north India: DEVTA, a cluster-randomised trial. Lancet 2013; 381(9876):1469-1477.

35. Benn CS, Aaby P, Arts RJ, Jensen KJ, Netea MG, Fisker $A B$. An enigma: why vitamin A supplementation does not always reduce mortality even though vitamin A deficiency is associated with increased mortality. Int $J$ Epidemiol 2015; 44(3):906-918.

36. Halpern R, Victora CG, Barros FC, Horta BL, Giugliani ERJ. Fatores de risco para suspeita de atraso no desenvolvimento neuropsicomotor aos 12 meses de vida. Jornal de Pediatria 2000; 76(6):421-428.

37. Correia LL, Campos JS, Andrade FMdO, Machado MMT, Lindsay AC, Leite AJ, Rocha HA, Cunha AJ. Prevalence and determinants of child undernutrition and stunting in semiarid region of Brazil. Rev Saude Publica 2014; 48(1):19-28.

Artigo apresentado em 17/05/2017

Aprovado em 17/11/2017

Versão final apresentada em 19/11/2017 